\section{EMBRYRIDDLE}

Aeronautical University

SCHOLARLY COMMONS
Journal of Aviation/Aerospace

Education \& Research

Volume 3

Number 2 JAAER Winter 1993

Article 1

Winter 1993

\title{
Airline Employee Slowdowns and Sickouts as Unlawful Self Help: A Statistical Analysis
}

Wm Francis Herlehy III, Ph.D.

Tracy Ingalls-Ashbaugh

Follow this and additional works at: https://commons.erau.edu/jaaer

\section{Scholarly Commons Citation}

Herlehy, W. F., \& Ingalls-Ashbaugh, T. (1993). Airline Employee Slowdowns and Sickouts as Unlawful Self Help: A Statistical Analysis. Journal of Aviation/Aerospace Education \& Research, 3(2). https://doi.org/ 10.15394/jaaer.1993.1090

This Article is brought to you for free and open access by the Journals at Scholarly Commons. It has been accepted for inclusion in Journal of Aviation/Aerospace Education \& Research by an authorized administrator of Scholarly Commons. For more information, please contact commons@erau.edu. 


\section{AIRLINE EMPLOYEE SLOWDOWNS AND SICKOUTS AS UNLAWFUL SELF HELP: A STATISTICAL ANALYSIS}

Wm. Francis Herlehy III, Ph.D. and Tracy Ingalls-Ashbaugh

\section{ABSTRACT}

Labor relations literature and numerous trade journals are replete with stories of labor slowdowns and sickouts. The consequences of this usually illegal activity are minimal because of the difficulty, if not impossibility, of proving a concerted effort. The authors suggest a means by which "slowdown" activity as a matter of chance can be ruled out. Further research suggestions are offered.

\section{INTRODUCTION}

Aviation collective bargaining has been widely employed and severely tested in recent years as the industry has felt the strain of foreign competition, deregulation and intense intra-industry competition. In the airline sector of the industry, these factors along with declining traffic and skyrocketing fuel costs have led to chaotic and bitter labor/management relations. Although the airline industry has been marked by several turbulent collective bargaining situations since deregulation, work stoppage activity in the past decade has declined. Once a potent economic tool for airline laborers, the strike has not been particularly effective in recent years.

\section{Decreased Use of Strikes}

Many factors contribute to the decreasing use of strikes. A sluggish economy bred laborers' financial concerns and allowed for a plentiful pool of replacements. Often there are incentives, such as enhancing seniority, to individuals who cross picket lines. "The government's firing of 11,000 striking air traffic controllers in 1981 set a tone of at least implicit government approval of aggressive management response to union strikes" (McDonald \& Asher, 1989, p. 350). An overall diminished support for unions has affected both the number of employees willing to honor a strike and a strike's ability to generate public support.

The public is not inclined to sympathize with any union, especially pilots. "When it comes to strikes, the actions usually revolve around the pilots because they can shut down an airline so convincingly" (Fotos, 1990 , pp. 56-57). Most airline unions need the support of the pilots for an effective shut down of the carrier, but greater numbers of union members are refusing to honor their colleagues' picket lines. Furthermore, for a pilot strike to be successful pilots must not be quickly replaced and, if they are, the public must sympathize and refuse to fly the "struck" airline. According to Aviation Week \& Space Technology, however, "Pilots have a hard time getting sympathy. The public image of pilots consists of $\$ 100,000$ salaries given to people who don't work very many hours a week" (Fotos, 1990 , pp. 56-57). The great publicity given to the recent contract agreement between Delta Airlines and its pilot's union, which gave captains of wide-bodied jumbo jets $\$ 176,130$ after 12 years, is an example of the influences on the ticket paying public regarding pilots' "glamorous assignments" and high salaries (Hayes, 1991).

In Collective Bargaining: $A$ Union Perspective, the Air Line Pilots Association's Director of Representation has stated that the strike is "no longer an effective bargaining tool," which has resulted in "a profoundly altered balance of power in the collective bargaining process" (Rosen, 1988, pp. 11, 15). Therefore, since the effective- 
ness of the strike is highly questionable, unions have begun to employ alternative methods of self help. Among these methods of instituting governmental pressure, the "corporate campaign" including advertising, work slowdowns, and employee sickouts.

\section{Alternative Methods of Self Help}

By exposing alleged circumstances of mismanagement to the Department of Transportation (DOT) and the Federal Aviation Administration (FAA), unions have attempted to gain leverage by putting governmental pressure on specific carriers.

Labor's challenge before the DOT of

TWA's fitness to operate, and its assault on Eastern before Congress, the FAA, and a specially formed Citizens Commission of Inquiry into Texas Air Corp. are recent examples. (McDonald \& Asher, 1989, p. 354).

This method of self help requires considerable time and financial resources and its effectiveness is of yet uncertain.

The corporate campaign involves a dramatic presentation to the public, frequent flyers, travel agents, stockholders, and lenders exposing the alleged unbalance of the bargaining positions. It often involves contacting travel agents to encourage them to book their clients on other airlines, calling into question the safety practices of the airline, and staging demonstrations and rallies at hub airports. The union also has used campaigning in the form of radio and television advertisements aimed at improving its image and influence with the public. "While such campaigns are generally considered to be lawful, they require careful planning and substantial resources in order to be successful, and even then the 'success' of such a campaign is difficult to measure" (McDonald \& Asher, 1989, p. 354).

According to McDonald and Asher (1989), the unions' principal remaining tools of economic pressure are work slowdowns and employee sickouts. When instigated by a sufficient number of members, these tactics can significantly disrupt a carrier's on-time performance and even cause flight cancellations. The resulting loss of revenue, poor customer service and tarnished public image can be successful in gaining unions economic bargaining power. "The genesis of such actions is difficult to detect, and they often may be masked in a professed concern for safety" (McDonald \& Asher, 1989, p. 355).

\section{Statement of the Problem}

Unions members are forbidden from work slowdowns and sickouts under the Railway Labor Act of 1936. The law, which applies to airlines and their labor groups, requires a prolonged series of actions before airline unions can act outside negotiations. Union inspired job actions, however, are difficult to prove. Knowing that injunctions may be granted to halt these forms of economic pressure, union leaders are cautious not to expose any direct evidence and are prepared with myriad denials and alternative explanations. "As unions have become more sophisticated over the years, the likelihood that they will leave many 'smoking guns' for the carrier to seize upon as direct evidence to support an injunction has decreased" (McDonald \& Asher, 1989, pp. 355-356). Thus, the difficult task of proving union responsibility for work slowdowns and employee sickouts falls upon the airline carrier.

Statistical analysis, however, provides a means by which carriers may defend their accusations. The methods of analysis, described in McDonald and Asher's (1989) article will determine whether slowdowns and sickouts occurred strictly by chance or if 
it can be inferred they were union organized. The inference can be supported by demonstrating that the chances a particular job action occurred purely by chance are unusually high. Statistics showing measure of relationship are also effective for determining whether job actions were union organized. Union responsibility for slowdowns can be inferred when periods of "negotiation" and periods of "no negotiation" show significantly different occurrences of job actions. According to McDonald and Asher (1989), such a showing provides a powerful repudiation of union officials denial of responsibility and should establish at least a prima facie case of union orchestration (McDonald \& Asher, 1989).

\section{Statement of the Purpose}

In this research project, the authors will first define and discuss work slowdowns and employee sickouts. Second, the actions of American Airlines management and its pilot's union, the Allied Pilots Association, during their contract negotiation period from January 1990 through January 1991 will be presented. Third, the Railway Labor Act, which prohibits slowdowns and sickouts, will be examined. Finally, statistical analyses will be applied to the American Airlines example. The null hypothesis to be tested is that no relationship exists between the negotiation period and the on-time performance record of the airline.

\section{REVIEW OF SLOWDOWNS}

\section{AND SICKOUTS}

"Industrial guerilla warfare-in the form of work slowdowns and employee sickouts-has staged a comeback in recent times, particularly in the airline industry" (McDonald \& Asher, 1989, p. 356). As the strike has become a less effective economic tool against airline management, the unions have turned to purposefully creating interruptions in their daily responsibilities. Examples of these slowdowns, or insider retaliations, are Northwest baggage handlers misrouting bags, and American flight attendants leisurely distributing food trays and reporting safety violations to the FAA (Conway, 1988).

One slowdown technique immensely effective for pilots is "work to rule." Because of the enormous decision making power pilots have over whether an aircraft is fit to fly, their means of slowing down a departure or even canceling a flight are virtually endless. Checklists are performed to the letter and minor repairs are insisted upon rather than overlooked or postponed to the end of the day. Pilots may even take the slowdowns one step further by creating the need for repair themselves or by not identifying the need until arriving at a station where the airline does not employ maintenance personnel. Thus, the pilot costs the airline time and money to bring in another carrier's maintenance workers. Most important, however, is that accusations from management of slowdown job actions are refuted by insistence that workers are protecting passenger safety.

Another slowdown tactic involves manipulating flight operations so as to intentionally arrive more than 15 minutes late. In compiling statistics of on-time performance records for the airlines, the DOT considers arrivals to be on time if they are not more than 15 minutes late. Thus, forcing arrivals to be 16 minutes or more later than the published time adversely affects a carrier's performance rating.

Among the many methods used to delay flights is to follow Federal Aviation Regulations (FARs) and air carrier operations manuals exactly. "For example, pilots may insist on instrument approaches 
in clear weather or on repeating verbatim all air traffic controller instructions" (McDonald \& Asher, 1989, p. 358). Simpler means of achieving the 16 minute late arrival include taxiing slowly, ordering elaborate maintenance checks, and slowing the speed of the aircraft by carrying too much fuel (United Air's, 1989). To add greater expense to their tardiness tactics, pilots also start all three engines immediately rather than just one which is ordinarily used until takeoff.

The slowdown is an effective negotiation tool for unions because it produces real and/or potential economic pressure. Burning excessive amounts of fuel and requiring additional maintenance become immediate costs to the airline. Carriers also lose revenue instantly when cancellations force them to accommodate travelers on competing airlines. The delaying and canceling of flights, along with passengers becoming victims of job slowdowns, could potentially produce loss of market share by travelers taking their business to other carriers. Disciplining the offenders and seeking injunctive relief are virtually the carrier's only options. Discipline cannot be enforced, however, if the action was solely following procedures to the letter. Without proof of union responsibility, injunctive relief is difficult, if not impossible, to obtain (McDonald \& Asher, 1989).

"A sickout, if sufficiently widespread, can cause the same magnitude of disruption to service as can a slowdown, with flights being delayed or canceled for lack of crews" (McDonald \& Asher, 1989, p.360). Although organized sickouts are more obvious than work slowdowns, they are just as difficult to prove. Plans are passed by word of mouth, leaving no direct evidence, and often medical reports are provided for use as possible explanations.

\section{REVIEW OF THE STUDY SAMPLE:} AMERICAN AIRLINES

In July of 1991 Business Week author, Wendy Zellner, wrote:

Already, some disgruntled pilots seem to be delaying flights be working strictly by the book, helping push American into the No. 9 spot on the Transportation Dept.'s list of on-time performance for airlines in March and April. The company was No. 7 in February and No. 2 in the last quarter of 1989. (Zellner, 1990, p. 33)

American Airline's five year pilot contract expired in December 1989. Contract talks, however, began the previous October with the hopes of meeting a self imposed negotiation deadline in January 1990. As the deadline approached, management and the pilots' union, the Allied Pilots Association, were too far apart, and talks broke down. In July 1990, talks resumed in Miami under the direction of a federal mediator, Harry Bickford. No agreement was reached from those talks, and Bickford was quoted as saying "this is a classic labor dispute" (Zellner, 1990, p. 33).

A fundamental disagreement on the airline's long term profitability, with pilots holding a more optimistic view than management, continued to prolong the negotiations and invite job actions (Fotos, 1990). Pilots wanted significantly improved benefits and wages, including a shorter time on the lower wage tier. The company would not offer the rates equivalent to Delta that the pilots were demanding. Zellner stated there was "growing militancy among the union's board members" and that directors wanted "a tougher negotiating stance" (Zellner, 1990, p. 33). Evidence of job actions to gain union bargaining power began surfacing as negotiations were drawn 
out. An APA leader, Dana R. MacKimmie, was quoted as saying "I think (Crandall) knows in a service industry that you have to address the concerns of the employees" (Zellner, 1990, p. 33).

On November 5, 1990, American's President, Robert Crandall, sent a letter to the APA's President, Fred Vogel, charging the union with instigating a job slowdown. "Crandall wrote, 'Some members of the association, with active support of APA representatives, have for many months been engaged in slowdown activities designed to damage the company's operations" (Fotos, 1990, pp. 36-37). The union replied by denying the allegations and stating that disgruntled individuals were likely acting on their own. Amid the growing unrest, American made a contract proposal to the union which was instantly rejected. Robert W. Baker, American's executive vice president of operations, responded by sending out a letter to all 8800 pilots stating, "You might as well understand, guys, you're not going to get Delta rates'" (O'Brian, 1991, p. c13).

A B-scale pilot, who asked not to be identified, was quoted by O'Brian (1991, p. c13) as saying "The mood (among pilots) shifted after that. Now nobody is happy with the company." Aviation Week \& Space Technology reported that later in the week anonymous computer generated messages appeared on bulletin boards in American's flight rooms with messages like "Coming soon to an airport near you--gridlock! (The Crandall Crawl) Nov 21-23" (Fotos, 1990, pp. 36-37).

American was already fighting the apparent slowdown, and as the contract dispute continued, the union allegedly called for a sickout. On December 23 at Dallas/Ft. Worth Airport the carrier canceled 74 flights (about $9 \%$ of its flights), due to an increase in the number of pilots calling in sick (Solomon, 1990). Travel Weekly writer, Rik Fairlie (1991), reported the holiday sickout as follows:

As of early January, American said the number of its pilots calling in sick hovered just below 400 per day, which is approximately $35 \%$ above normal. 'During the peak holiday travel periods,' the spokesman said, 'an average of 525 pilots called in sick per day, or $70 \%$ above normal, inconveniencing some 60,000 passengers.' (Fairlie, 1991, p. 4)

The union claimed the airline was unfairly blaming members for cancellations caused by bad weather, winter illness and pilots in active reserve duty for Operation Desert Shield.

American received a temporary restraining order on December 26, from U.S. District Court Judge, John McBryde, barring the APA from organizing or encouraging activities aimed at disrupting the carrier's operations. The airline alleged the union had been waging illegal job actions.

In his order, Judge McBryde said that he granted the request because the airline 'is likely to prevail on the merits of its claims' and that the 'disruptive activity' could 'cause American Airlines to suffer a substantial loss of revenue and passenger goodwill which it can never recover.' (Solomon, 1990, p. A3)

The restraining order required the union to notify its members to refrain from taking part in any mass sickout, slowdown, or other actions to disrupt the airline's operations. Aviation Week \& Space Technology reported, however, that:

Despite this (the restraining order) 
airline officials said, the number of pilots calling in ill each day continued to range between 500 and 525 through Dec. 31. During the first two days of January, the number calling in ill dropped to about 400 , still well above normal, the officials said. Other disruptive actions continue to be encountered .... including reports of nonexistent mechanical malfunctions, and other minor actions. (Brown, 1991, p. 37)

On January 2, and for several consecutive days, American engaged in campaigning of its own. The company placed advertisements in 23 major newspapers apologizing for delays and cancellations during the holidays, and blaming the disruptions on the pilot's illegal job actions. The union responded with alternative explanations such as over scheduling, widespread influenza, and pilots lost to Operation Desert Shield. According to The Wall Street Journal:

The union also released a letter its president, Fred Vogel, wrote to the FAA alleging American's ground crews make frequent mistakes when figuring the weight of departing aircraft. Such errors, the union claimed, 'demonstrate a growing loss of safety and increasing numbers of flights where the public has been endangered.' (O'Brian, 1991, c13)

Also on January 2, American announced it would reduce flights by $4 \%$ to compensate for crews calling in sick. Three days later, flight reductions were increased to $11 \%$. "We cannot chance another situation like .... the recent holiday." said Robert W. Baker, an American executive vice president in explaining the $11 \%$ cut. The unions refuted by declaring there was over capacity in the industry and that pilots were not as badly needed during this period because air travel was down considerably, the economy was poor, and the war was driving up fuel costs (O'Brian, 1991).

Negotiations resumed in W.ashington on January 7, 1991 before federal mediators. An impasse appeared inescapable on January 31 when American presented its final offer and the ALPA refused to take it to its membership. On February 9 after an all-night session an agreement was made to enter into binding arbitration.

\section{SLOWDOWNS AND SICKOUTS}

AS UNLAWFUL SELF HELP

Although American's pilots had been working without a contract since December 30,1989 , they were forbidden from work slowdowns, strikes and other actions under the Railway Labor Act. The act requires air carriers and their employees, in the process of contract negotiations, to follow mandatory resolution procedures. First, if the two sides cannot agree, either party can petition for a federally appointed mediator. In the example, when American and the APA did not resolve their differences by their self-appointed deadline, Harry Bickford of the National Mediation Board was called in. If the two sides still cannot agree, the mediator can declare them to be at an impasse and enter a thirty day cooling off period. "Through this entire process, including the thirty-day cooling off period, 'neither party may unilaterally alter the status quo" (McDonald \& Asher, 1989, pp. 361-62). If the entire period ends without a new contract, the union is free to strike and the company is able to impose any work rules and pay it chooses.

The Railway Labor Act's status quo provision prohibits work slowdown and employee sickouts during the entire contract negotiation period. The status quo is 
intended to maintain working conditions existing before the dispute arose, including labor practices not specifically included in the collective bargaining agreement. The tactics of American Airline's employees to disrupt operations, were in violation of the status quo, and the means for relief, an injunction, was sought.

In order to win an injunction, the court must find evidence of disruption of the status quo, concerted action (or inaction) on the part of union members, and financial harm to the carrier. Financial harm is often in the form of the loss of customer goodwill. In American's case, Judge McBryde found that management's claims were reasonable, there was evidence of disruption of operations, and American had suffered irreparable loss. Although the union may not have been proven to be directly responsible for the disruption, McDonald and Asher (1989) point out in their cited article two methods, other than direct evidence, where courts may find union responsibility. The first is that both parties have a duty to settle disputes without interrupting service, and any union official's inaction to take serious measures to stop job actions is in violation. The second is the mass action theory, which justifies union responsibility. by asserting that large scale slowdowns or sickouts do not just happen without organization.

\section{Subjects}

\section{ANALYSIS OF THE SAMPLE}

The data to be used are the overall percentages of reported flight operations arriving on time for American Airlines as reported to the DOT. Airlines are required by 14 CFR Part 234 of DOT's regulations to file the information with the DOT each month. Data is reported for nonstop scheduled time shown in the carriers'
Computerized Reservations Systems (U.S. Department of Transportation, 1991). Time periods of the data to be used for analysis are: September 1987 to January 1988, September 1988 to January 1989, September 1989 to January 1990, and September 1990 through January, 1991. See Table 1 for data to be analyzed.

\section{TABLE 1}

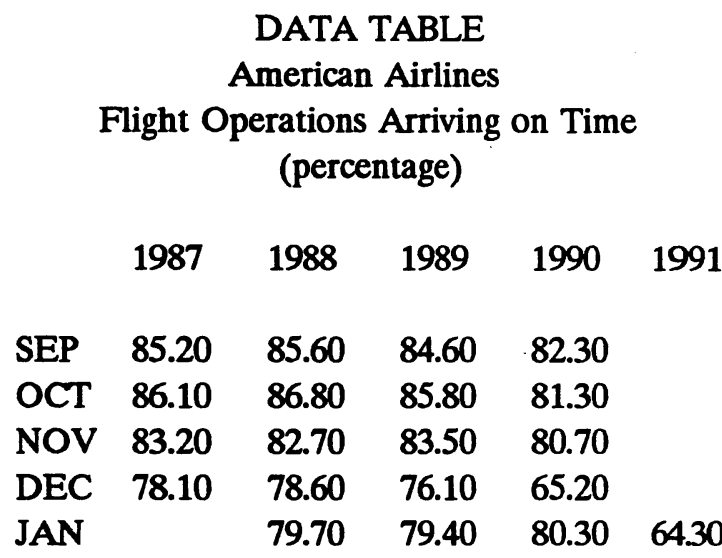

Source:. U.S. Department of Transportation. Consumer Affairs Office. Air Travel Consumer Report Washington: GPO, 19871991.

Sample selection is based upon alleged slowdowns occurring during the contract negotiation period July 1990 to January 1991. The September to January time period is used because data for July and August 1987 are unobtainable. The years 1987,1988 , and 1989 are used for control.

\section{Instruments}

The statistical measurements to be calculated include; two measures of central tendency, a measure of variability, and a measure of relationship. The two measures of central tendency to be calculated are the median and the mean. These measures of central tendency were chosen to represent 
the typical percentage of on-time performance for each time period.

Individual months during those periods will then be observed for variance. The standard deviation is used as the measure of variability because it is the most stable measure of variability and takes into account each and every score. It will indicate whether the on-time performance percentages during a time period are relatively close to one another or whether they are spread out (large variance). Use of the mean and the standard deviation provide a relatively clear picture of the distribution of the on-time percentages for each period. The measure of relationship to be used is the Pearson $r$. The Pearson $r$ was chosen because it takes into account each and every score in both distributions, and it is the most stable measure of correlation. The Pearson $r$ measure of relationship, or correlational measure, is used to determine if, and to what degree, a relationship exists between the on-time performance during the periods of no negotiations and the on-time performance during the period of negotiations. The level of significance to be used is .01 .

\section{Design}

The measures of central tendency and variance are observed to determine whether it is feasible that a significant difference exists between the negotiation period, September 1990 to January 1991, and the control periods. Because the negotiation period in 1990 carried through January of 1991, January of each year is included in the previous year. For example, the time period from September 1990 to January 1991 is presented as September-January 1990, or may simply be presented as January in the year 1990. This is done in order to simplify the information and analysis. The mean, median and standard deviation will then be observed to see whether they support the graphic conclusion. If a significant difference appears probable, the Pearson $r$ test for relationship is calculated.

The on-time performance during the control years is measured against one another to determine if a relationship exists. The ontime performance will then be measured against the on-time performance during the negotiation period, 1990, to determine whether a relationship exists.

\section{RESULTS}

The means and standard deviations appeared to support this conclusion because the mean on-time performance during 1990 was lower than those of the control years, and the standard deviation for 1990 showed a large variance. The large variance indicated that there were months that significantly differed from the mean on-time percentage. (See Table 2.)

\section{TABLE 2}

\begin{tabular}{|c|c|c|c|c|}
\hline \multicolumn{5}{|c|}{$\begin{array}{c}\text { DATA TABLE } \\
\text { American Airlines } \\
\text { Flight Operations Arriving on Time } \\
\text { (percentages) } \\
\text { Mean, Median, and Standard Deviation }\end{array}$} \\
\hline & 1987 & 1988 & 1989 & 1990 \\
\hline IEAN & 82.46 & 82.62 & 82.06 & 74.7 \\
\hline MEDIAN & 83.2 & 82.7 & 83.5 & 80.7 \\
\hline $\begin{array}{l}\text { STANDARD } \\
\text { DEVIATION }\end{array}$ & 3.46 & 3.64 & 3.91 & \\
\hline
\end{tabular}

Source: U.S. Department of Transportation. Consumer Affairs Office. Air Travel Consumer Report. Washington: GPO, 1987-1991.

The Pearson $r$ was calculated based on 
findings thus far. For the hypothesis to be rejected, indicating that a statistically significant relationship does exist between the negotiation period and the on-time performance of the airline, a statistically significant relationship would have to be found between the on-time performance of each pairing of the control years, and no statistically significant relationship could be found between the on-time performance of any of the control years and the negotiation period.

\section{TABLE 3}

\section{DATA TABLE \\ American Airlines \\ Flight Operations Arriving on Time (percentages) \\ Measure of Relationship-Pearson $\mathbf{r}$}

\begin{tabular}{|c|c|c|}
\hline Years & Result (r) & Conclusion \\
\hline 1987 to 1988 & .9901 & significant relationship \\
\hline 1987 to 1989 & .9695 & significant relationship \\
\hline 1987 to 1990 & .9414 & not significant \\
\hline 1988 to 1989 & .9656 & significant relationship \\
\hline 1988 to 1990 & .9185 & not significant \\
\hline 1989 to 1990 & .8903 & not significant \\
\hline degrees of freer & $=3$ & level of significance $=.01$ \\
\hline
\end{tabular}

The Pearson $r$, measure of relationship, indicates that a statistically significant relationship does exist between the on-time performance of each pairing of the control years and that a statistically significant relationship could not be shown between the on-time performance for any of the control years and the on-time performance during 1990. (See Table 3.)

Therefore, the null hypothesis was rejected because not only was there a statistically significant relationship between each pairing of the control years, but in addition no statistically significant relationship was shown between any one of the control years and the negotiation period, 1990.

\section{CONCLUSIONS AND DISCUSSION}

The results of the analysis warrant rejecting the hypothesis. There is a statistically significant relationship between the negotiation period and the on-time performance record of the airline.

The differences observed, the means and standard deviations, are probably the result of organized slowdown activity sufficient enough to cause a significant difference between the year they occurred and previous years.

The results of this analysis clearly indicate that a statistically significant relationship exists between a period of contract negotiations and employee slowdowns or sickouts.

Establishing a statisticaliy significant relationship between negotiations and slowdowns could have used different measures of slowdowns. The same statistical procedures used in this study could have been followed using (a) the number of sickouts, (b) the number of flight cancellations, or (c) the number of maintenance reports submitted by pilots and the same time periods.

Further research, likely necessary to obtain an injunction, would need to include additional control data such as flights by airport and a comparison of on-time performance by month to that of other comparable air carriers.

The important fact for airline managers is that statistical procedures are available to 
assist in providing reasonable proof of union responsibility for illegal job actions.

Wm. Francis Herlehy III, Ph.D., an associate professor of aviation business administration with Embry-Riddle Aeronautical University, has represented the U.S. Dept. of Labor, the NM Dept. of Labor, and the NLRB in various labor/management disputes and cooperative activities.

Tracy Ingalls-Ashbaugh holds both a BS and MS in marketing and also the Master of Aeronautical Science in aviation management. She is the chief operating officer for an agency specializing in corporate and group travel.

\section{APPENDIX A}

$$
\text { MEAN }=\frac{\Sigma X}{\mathrm{~N}}
$$

$$
\begin{aligned}
& \text { STANDARD } \\
& \text { DEVATION }
\end{aligned}=\sqrt{\frac{\Sigma \mathrm{X}^{2}-\frac{(\Sigma \mathrm{X})^{2}}{\mathrm{~N}}}{\mathrm{~N}-1}}
$$

\begin{tabular}{|c|c|c|c|c|c|c|c|}
\hline & \multicolumn{7}{|c|}{ APPENDIX B } \\
\hline & \multicolumn{3}{|c|}{ 1987-1988 } & \multicolumn{4}{|c|}{ 1988-1989 } \\
\hline$\Sigma x$ & $=\quad 412.3$ & $\Sigma Y$ & $=\quad 413.1$ & $\Sigma x$ & $=\quad 413.1$ & $\Sigma Y$ & $=410.3$ \\
\hline$(\Sigma x)^{2}$ & $=169991.29$ & $(2)^{2}$ & $=170651.61$ & $(\Sigma X)^{2}$ & $=170651.61$ & $(\Sigma)^{2}$ & $=168346.09$ \\
\hline$\Sigma X^{2}$ & $=34046.19$ & $\Sigma Y^{2}$ & $=34183.21$ & $\sum x^{2}$ & $=34183.21$ & $\Sigma Y^{2}$ & $=33730.35$ \\
\hline$\Sigma X Y$ & $=34114.08$ & $\mathbf{r}$ & $=\quad .9901$ & $\mathbf{E X Y}$ & $=33951.93$ & $r$ & $=.9656$ \\
\hline \multicolumn{4}{|c|}{ 1987-1989 } & \multicolumn{4}{|c|}{$1988-1990$} \\
\hline$\Sigma x$ & $=412.3$ & $\mathbf{z Y}$ & 410.3 & $2 x$ & $=413.1$ & $\Sigma Y$ & 373.8 \\
\hline$(\Sigma x)^{2}$ & $=169991.29$ & $(2)^{2}$ & $=168346.09$ & $(2 x)^{2}$ & $=170651.61$ & $(2 Y)^{2}$ & $=139726.41$ \\
\hline $2 x^{2}$ & $=34046.19$ & $\Sigma Y^{2}$ & $=33730.35$ & $2 x^{2}$ & $=34183.21$ & $\Sigma Y^{2}$ & $=28281.0$ \\
\hline$\Sigma X Y$ & $=33885.82$ & $\mathbf{r}$ & $=\quad .9695$ & $\mathbf{Z X Y}$ & $=31005.75$ & $\mathbf{r}$ & $=\quad .9185$ \\
\hline \multicolumn{4}{|c|}{$1987-1990$} & \multicolumn{4}{|c|}{$1989-1990$} \\
\hline$\Sigma x$ & $=412.3$ & $\Sigma Y$ & $=373.8$ & $\Sigma x$ & $=410.3$ & $\Sigma Y$ & $=373.8$ \\
\hline$(2 x)^{2}$ & $=169991.29$ & $(2)^{2}$ & $=139726.44$ & $(\Sigma x)^{2}$ & $=168346.09$ & $\left(\Sigma \eta^{2}\right.$ & $=139726.41$ \\
\hline$\Sigma x^{2}$ & $=34046.19$ & $\Sigma Y^{2}$ & $=28281.0$ & $\Sigma x^{2}$ & $=33730.35$ & $\Sigma Y^{2}$ & $=28281.0$ \\
\hline$\Sigma X Y$ & $=30942.96$ & $\mathbf{r}$ & $=\quad .9414$ & $\Sigma X Y$ & $=30801.58$ & $r$ & $=.8903$ \\
\hline
\end{tabular}

$$
\text { PEARSON } r=\frac{\Sigma X Y-\frac{(\Sigma X)(\Sigma Y)}{N}}{\sqrt{\left[\Sigma X^{2}-\frac{(\Sigma X)^{2}}{N}\right]} \sqrt{\left[\Sigma Y^{2}-\frac{(\Sigma Y)^{2}}{N}\right]}}
$$




\section{REFERENCES}

Brown, D. A. (1991, January 7). Airline blasts pilots for delays; contract talks climate sours. Aviation Week \& Space Technology, p.37

Conway, J. E. (1988). Standards governing permissible self-help. In J. McKelvey (Ed.), Cleared for Takeoff: Airline Labor Relations Since Deregulation, (pp. 201, 214). Ithica, NY: Cornell University, ILR Press.

Fairlie, R. (1991, January 14). AAL runs 3 full-page ads to apologize for apology. Travel Weekly, p.4.

Fotos, C. P. (1990, November 26) Frustration grows as pilots mull proposed american pact. Aviation Week \& Space Technology, pp. 36-37.

Fotos, C. P. (1990, December 24). Labor relations putting U.S. airlines at crossroads. Aviation Week \& Space Technology, pp. 56-57.

Hayes, T. C. (1991, February 2). American and pilots brace for strike. The New York Times, p. 8L.

McDonald, J. J. \& Asher, E. (1989). Airline employee slowdowns and sickouts as unlawful self help: A legal and statistical analysis. Journal of Air Law and Commerce, $\underline{55}$ (Winter), pp. 349-381.

O'Brian, B. (1991, January 7). American air to ground $11 \%$ of its flights. The Wall Street Journal, p. A3-4.

O'Brian, B. (1991, January 30). American airlines faces labor impasse. The Wall Street Journal, p. C13.

Railway Labor Act. (1962). Pub.L. No. 487, 49 Stat. 1189, 1936. As amended Title 45, pp. 151-188

Rosen, S. D. (1988). Collective bargaining:. A unions perspective. In J. McKelvey, J. (Ed.), Cleared for Takeoff: Airline Labor Relations Since Deregulation (pp. 11, 15). Ithica, NY: Cornell University, ILR Press.

Solomon, C. (1990, December 28). American air wins temporary order barring its pilots union from sickouts. The Wall Street Journal, p. A3.

United Air's performance has taken big dive, hurt by pilots' union action. (1989, September 18). The Wall Street Journal, P. A4.

U.S. Department of Transportation. (1987-1991) Office of Consumer Affairs. Air Travel Consumer Report. Washington, DC: Government Printing Office.

Zellner, W. (1990, July 2) The pilots at american are up--in arms. Business Week, p. 33. 